REVIEW

This paper is dedicated to the $70^{\text {th }}$ anniversary of the founding of Physiologia Bohemoslovaca (currently Physiological Research)

\title{
The Anti-Obesity and Health-Promoting Effects of Tea and Coffee
}

\author{
Alexander V. SIROTKIN ${ }^{1}$, Adriana KOLESAROVA ${ }^{2}$ \\ ${ }^{1}$ Faculty of Natural Science, Constantine the Philosopher University in Nitra, Nitra, Slovak \\ Republic, ${ }^{2}$ Faculty of Biotechnology and Food Sciences, Slovak University of Agriculture in Nitra, \\ Nitra, Slovak Republic
}

Received March 7, 2021

Accepted March 18, 2021

\section{Summary}

This paper reviews provenance, chemical composition and properties of tea (Camelia sinensis L.) and coffee (Coffee arabica, L. and Coffea caniphora, L.), their general health effects, as well as the currently available knowledge concerning their action on fat storage, physiological mechanisms of their effects, as well as their safety and recommended dosage for treatment of obesity. Both tea and coffee possess the ability to promote health and to prevent, to mitigate and to treat numerous disorders. This ability can be partially due to presence of caffeine in both plants. Further physiological and medicinal effects could be explained by other molecules (theaflavins, catechins, their metabolites and polyphenols in tea and polyphenol chlorogenic acid in coffee). These plants and plant molecules can be efficient for prevention and treatment of numerous metabolic disorders including metabolic syndrome, cardiovascular diseases, type 2 diabetes and obesity. Both plants and their constituents can reduce fat storage through suppression of adipocyte functions, and support of gut microbiota. In addition, tea can prevent obesity via reduction of appetite, food consumption and food absorption in gastrointestinal system and through the changes in fat metabolism.

\section{Key words}

Obesity • Adipocyte • Tea • Coffee • Metabolism • Food consumption

\section{Corresponding author}

A. V. Sirotkin, Dept. Zoology and Anthropology, Constantine the Philosopher University in Nitra, Tr. A. Hlinku 1, 94974 Nitra, Slovak Republic. E-mail: asirotkin@ukf.sk

\section{Introduction}

Tea and coffee are the most popular drinks, the most highly traded and valued commodities that originates from the developing world. Their global consumption is permanently increasing due to their sensory and health properties. They can help in preventing and combatting obesity - the current world's pandemics. World's leading cause of death are diseases related to metabolic dysfunctions. The most significant in this aspect is overweight, which affects 1.9 billion of people around the world, of whom 650 millions are obese (Haider and Larose 2019). Obesity and overweight can facilitate diabetes, cause inflammations, cardiovascular and reproductive diseases as well as cancer (Skrypnik et al. 2017, Sung et al. 2018). In addition to these health risks, they are a cause of mobility issues, as well as problems in social and sexual relationships. They lower self-esteem and the overall quality of life. They also lead to considerable economic losses. Health care concerning patients with obesity incurs at least $25 \%$ higher expenditures and causes losses of 1-3.6\% of the gross domestic product of a country (Mohamed et al. 2014). Prevention and treatment of diseases using natural products and functional food of plant origin have always been the basis of folk and oriental medicine. Nowadays, they are experiencing a renaissance and their popularity is growing even in the official medicine and self-treatment. Coffee and tea could be promising candidates for prevention and treatments of various diseases including obesity. 


\section{Provenance and properties}

Tea

Tea tree (Camelia sinensis, L.) is a bush or a small tree from the Theaceae family grown in tropic and subtropical regions around the world. In Southeast Asia, the most common cultivar is Camellia sinensis sinensis, in India and on Ceylon - Camellia sinensis assamica. Based on the processing method (fermentation in the presence of bacteria or oxidation) and the taste, colour, aroma and biological effect of the tea, we recognize white, green, matcha, black, oolong, and $\mathrm{Pu}-$ erh tea (Rothenberg et al. 2018, Tang et al. 2019).

Despite most of Europe and the New World being accustomed to black tea, more antioxidants and tannins are present in non-oxidated and non-fermented white and green teas (Prasadh et al. 2019) and they also have a stronger benefit to health.

From the standpoint of biology and medicine, the most important are tea metabolites - alkaloid theobromine, its metabolite caffeine (1,3,7 trimethylxantin) and polyphenols (theaflavins), catechins epigallocatechin, epicatechin and their metabolites epigallocatechin gallate, epicatechin gallate. gallocatechins and gallocatechin gallate. Gallates contain biologically active ethers of gallic acid. Tea contains also smaller amounts of other biologically active polyphenols - quercetin, kaempferol and myricetin. Black tea contains also polyphenolic compounds theaflavins and thearubigins (Saeed et al. 2017, Khan and Mukhtar, 2018, Rothenberg et al. 2018, Tang et al. 2019). In addition to that, tea contains microelements borate, cobalt, copper, iron, manganese, molybdenite and lead (Karak et al. 2017), pigments, polysaccharides, alkaloids, free amino acids, and saponins (Tang et al. 2019).

\section{Coffee}

Coffee plant (Coffea spp.) is a short tree or a bush native to Africa, the fruits of which are red coffee "cherries." For preparation of drinks, two coffee species are used - Coffee arabica, L. (Arabica coffee) and Coffea caniphora, L. (Robusta coffee). The best-known molecule in this fruit is alkaloid methylxanthine caffeine (1,3,7 trimethylxantin) - a toxin, which protects the plant from herbivores. In addition to caffeine, coffee fruit contains alkaloid trigonelline, polyphenol chlorogenic acid, ferulic acid, diterpenes cafestrol and kahweol, melanoidins and coffee lipids and microelements (Ludwig et al. 2014, Islam et al. 2018, Stefanello et al. 2018).

\section{Positive effects on human health}

Tea

Polyphenols of green tea are efficient against chronic inflammatory conditions of liver, gastrointestinal tract, and against neurodegenerative diseases (Oz 2017). Anti-inflammatory effect of polyphenols can be explained by their action on gastrointestinal microbiota, which is responsible for immune responses (Yang et al. 2016).

Tea molecules at the right ratio counteract anxiety and stress (Unno et al. 2018). A link has been determined between green tea consumption and memory of older men. It is peculiar that the memory of older women was not affected (Xu et al. 2018).

Tea catechins can have an anti-tumour effect. They inhibit multiplication of cells, trigger their apoptosis (death) and autophagy and reduce vitality of cancer cells (Singh et al. 2018). They can even enhance the therapeutic effects of medicine against tumour diseases and simultaneously mitigate their adverse side-effects (Cao et al. 2016, Bedrood et al. 2018).

Most studies carried out on animals and humans report that tea (extract from tea tree leaves) reduces manifestations of metabolic syndrome, diabetes and cardiovascular diseases (including reducing the risk of heart attack) (Yang et al. 2018). Other studies demonstrated positive effect of tea on decreasing insulin in blood, but not on the concentration of glucose, triacylglycerols, fatty acids and hormones of adipose tissue (Mielgo-Ayuso et al. 2014, Li et al. 2016). Yang et al. (2016), however, reported that the reduced glucose levels in blood can be caused by the action of green tea polyphenols on glucose production in liver.

\section{Coffee}

Clinical studies demonstrated that the ability of coffee to reduce blood sugar is not dependent on caffeine but on its other components (Tunnicliffe and Shearer 2008). This effect probably comes from chlorogenic acid. Chlorogenic acid has antioxidant and anti-inflammatory effects, it can affect metabolism of glucose and lipids. Thanks to its antioxidant, anti-inflammatory and metabolic effects, coffee and its molecule chlorogenic acid have a preventive and therapeutic influence against diabetes, cardiovascular diseases, tumours, inflammation, lipidation of liver and Parkinson disease (Ludvig et al. 2014, Tajik et al. 2017, Islam et al. 2018, Perumpail et al. 2018). Their consumption can be recommended not only to healthy people but also to people with high cholesterol 
and blood glucose, with hypertension, metabolic syndrome (Sarriá et al. 2018, Xie et al. 2018) or diabetes (Tunnicliffe and Shearer 2008). Anti-diabetic effects were determined not only for chlorogenic acid but also for other acid components of coffee - caffeine and ferulic acid (Islam et al. 2018).

Large-scale studies showed a correlation between the habit of drinking coffee and reduced mortality linked to cardiovascular diseases, reduced risk of heart attacks and diabetes. Contrary to a popular belief, drinking coffee was not linked to increased occurrence of cardiac arrhythmias (Bhatti et al. 2013). Thanks to the ability of coffee's antioxidants to bind free radicals (Yashin et al. 2013) and to reduce diseases and mortality, coffee earned the title "longevity beverage" (Bhatti et al. 2013).

\section{Anti-obesity effects}

\section{Tea}

All performed studies (with the exception of Mielgo-Ayuso et al. 2014) validated the ability of tea and its components to reduce fat stores and body weight of humans (Huang et al. 2014, Janssens et al. 2016, Li et al. 2016, Pan et al. 2016, Vázquez Cisneros et al. 2017, Rothenberg et al. 2018, Yang et al. 2016, 2018).

This effect was achieved thanks to polyphenols (Pan et al. 2016, Silvester et al. 2019). According to the existing data, epigallocatechin and caffeine from tea leaves have independent mechanisms of effect but synergic effect on weight loss (Janssens et al. 2016, Türközü and Tek 2017, Vázquez Cisneros et al. 2017).

According to some sources, black tea polyphenols are more efficient than green tea polyphenols (Pan et al. 2016), but other authors report evidence of stronger effect of green tea (Yang et al. 2016).

It is presupposed that tea molecules reduce fat stores through several pathways (Huang et al. 2014, Pan et al. 2016, Yang et al. 2016, Rothenberg et al. 2018, Silvester et al. 2018, Willems et al. 2018):

- they influence neuroendocrine metabolic regulators of appetite and reduce food consumption (Huang et al. 2014),

- they reduce emulsion and absorption of lipids and protein in gastrointestinal system and consequently reduce calorie intake (Huang et al. 2014, Pan et al. 2016),

- they act on gastrointestinal microbiota (lactoand bifidobacteria), which are responsible for digestion. For example, they produce short fatty acids, which increase the rate of lipid metabolism (Yang et al. 2016, Rothenberg et al. 2018),

- they inhibit the differentiation and proliferation of preadipocytes, (Pan et al. 2016),

- $\quad$ they reduce lipid production (Huang et al. 2014, Yang et al. 2016),

- they promote lipolysis and lipid metabolism (Pan et al. 2016, Yang et al. 2016),

- they stimulate conversion of white adipose tissue to brown, increase its oxidation, burning and expenditure of energy through heat production (Huang et al. 2014, Silvester et al. 2018, Willems et al. 2018),

- they promote fecal lipid excretion (Huang et al. 2014).

However, it is necessary to take into consideration that the effect of green tea and its molecules manifests only when large doses are consumed. Vázquez Cisneros et al. (2017) recommended a daily dose of 100-460 mg of epigallocatechin gallate plus 80-300 mg of caffeine a day over the course of 12 and more weeks. Yang et al. $(2016,2018)$ recommended 3-4 cups of strong tea (600-900 mg of catechins) a day for at least 8 weeks minimum (Yang et al. 2018).

\section{Coffee}

The results of in vitro and animal studies suggest that coffee can reduce storing of fat in the body by several mechanisms:

- It inhibits multiplication of adipocytes (Pan et al. 2016),

- It influences transcription factors and other proteins involved in production of lipids in these cells (Tamura 2020),

- Through action on gastrointestinal microbiota, which can also affect obesity (Pan et al. 2016).

Thanks to these effects, coffee can reduce fat stores in obese animals and humans (Hasani-Ranjbar et al. 2009, Onakpoya et al. 2011, Pan et al. 2016, RíosHoyo and Gutiérrez-Salmeán 2018, Tabrizi et al. 2019, Tamura, 2020) and reduce body weight of humans (Hasani-Ranjbar et al. 2009, Onakpoya et al. 2011, Pan et al. 2016, Tabrizi et al. 2019). A study of Sarriá et al. (2018) determined a positive effect of green and roasted coffee on metabolic indexes but not on body weight of patients. 


\section{Possible adverse side-effects}

Tea

Tea consumption at a dose of 3 cups a day (Karak et al. 2017) or epigallocatechin gallate at a dose of $300 \mathrm{mg}$ a day over the course of 12 weeks (MielgoAyuso et al. 2014), or $704 \mathrm{mg}$ epigallocatechin gallate a day ( $\mathrm{Hu}$ et al. 2018) had no significant adverse sideeffects. No cyto- and genotoxic, mutagenic, carciogenic and embryotoxic effects of green tea were determined either (Bedrood et al. 2018).

Consumption of tea polyphenols can have a toxic effect on liver (Mazzanti et al. 2015) especially when consumed on empty stomach (Bedrood et al. 2018), or as pills rather than as beverage (Ho et al. 2018). Some studies reported the ability to caffeine to affect negatively the reproductive system - damage DNA, reduce sperm capacity and prolong pregnancy (Ricci et al. 2017).

\section{Coffee}

Caffeine in large doses can cause anxiety, insomnia, loss of calcium from the body and consequent increased risk of fractures, especially in people with osteoporosis (Bhatti et al. 2013). Possible negative effects of caffeine on brain development and development of reproductive organs in embryos and children have not been excluded (Islam et al. 2018). There are indications that caffeine and coffee can damage sperm and prolong pregnancy (Ricci et al. 2017). Cafestrol and kahweol can increase blood cholesterol levels (de Roos et al. 1999). Despite these findings, largescale studies found no statistically significant effect of coffee and caffeine consumption on the occurrence of health complications in adults, pregnant women, adolescents and children (Doepker et al. 2018) and conversely, they determined positive effect on health and longevity (see above).

\section{General evaluation and recommendations}

Tea

Tea belongs to humankind's favourite beverages. It has many positive effects on health. It is applied in prevention and treatment of a number of diseases. In Japan, green tea is added to everything including desserts and ice cream. Influence of tea on body weight reduction is conclusively validated by science. Considering its effects, it is possible to recommend it as a method of weight loss stimulation or an ingredient in food with added value. All types of tea have a positive effect on health and weight reduction. In medication, tea can be substituted by its functional components - epigallocatechin gallate and caffeine mixed at a given ratio.

However, it is necessary to remember that the effects of tea will manifest only at large doses (3-4 cups of strong tea a day, which represents 1-2 $\mathrm{g}$ of tea containing 100-600 mg polyphenols) and long-term use. Minimum length of the treatment is 8 weeks. For those not used to drink large amounts of tea, there is an alternative - condensed tea or its pure components. However, in that case its adverse side-effects on liver and reproductive system cannot be excluded.

\section{Coffee}

Scientific results validate coffee extract's application for weight loss and treatment of some metabolic disorders (diabetes, obesity, etc.). Coffee has a number of other positive physiological effects on health and longevity. Adverse side-effects of coffee are not serious and they manifest only when consumption is excessive. This knowledge allows to recommend coffee extract as an ingredient in a beverage intended for weight loss.

At present, the market offers numerous kinds of coffee. Naturally, a question arises as to which are the most efficient for weight reduction and at what dose.

\section{Is green coffee better for weight loss then roasted?}

During roasting of green coffee, so called Mallard Reaction metabolizes chlorogenic acid to antioxidant melanoid, which is responsible for the biological activity of this acid (Tunnicliffe and Shearer 2008, Dybkowska et al. 2017). Green coffee contains fewer antioxidants and polyphenols than roasted (Odžaković et al. 2016). This means that roasting increases rather than reduces the metabolic effects of coffee.

\section{Is decaffeinated coffee better for weight loss?}

Decaffeination decreases the antioxidant activity of coffee (Yashin et al. 2013). Tunnicliffe and Shearer (2008) proved that positive effects of coffee are not dependent on caffeine at all but instead on other components. Therefore, in relation to weight loss the presence or absence of caffeine in your coffee makes no difference. 
How much coffee to drink for weight reduction?

One strong cup of coffee contains $60 \mathrm{mg}$ of pure chlorogenic acid. This dose has essentially no effect on absorption of chlorogenic acid into the body (Williamson et al. 2011). Metabolic effect is achieved at daily intake of minimum $510.6 \mathrm{mg}$ of chlorogenic acid and $121.2 \mathrm{mg}$ of caffeine (Sarriá et al. 2018). In Canada, considered a safe dose for adults are $400 \mathrm{mg}$ of caffeine for one-time dose (Doepker et al. 2018). Drinking 5 cups of coffee a day had only positive effects on health (Carlström et al. 2018).

This evidence speaks in favor of roasted coffee extract with about $400 \mathrm{mg}$ of caffeine and/or $510 \mathrm{mg}$ of chlorogenic acid, which corresponds 3-5 cups of strong coffee a day to be used for weight reduction. This amount can be considered a metabolically efficient as well as safe dose. For those who cannot manage so many coffees a day, coffee can be replaced by an adequate amount of chlorogenic acid and caffeine.

\section{Conclusion}

Both tea and coffee possess the ability to promote health and longevity, as well as to prevent, to mitigate and to treat numerous disorders including obesity and obesity-related illnesses (Bhatti et al. 2013). This ability can be partially due to presence of caffeine in both plants. Further physiological and medicinal effects could be explained by other molecules, which are different in these plants, but which can have common antioxidant properties. The physiological effects of tea, besides caffeine, can be explained by presence of theaflavins, catechins, their metabolites and polyphenols quercetin, kaempherol and myricetin, whilst the physiological effects of coffee are probably related to caffeine and polyphenol chlorogenic acid (see above). Due to anti-oxidant and anti-inflammatory properties these plant molecules can be efficient for prevention and treatment of numerous metabolic disorders including metabolic syndrome, cardiovascular diseases, type 2 diabetes and obesity. Both plants and their constituents can prevent and reduce fat storage through suppression of adipocyte functions and support of gut microbiota. In addition, tea can prevent obesity via reduction of appetite and reduce food consumption and food absorption in gastrointestinal system and changes in fat metabolism.

It is necessary to keep in mind, that the antiobesity effects of both tea and coffee can be expressed only by intensive consumption of large amounts (3-6 cups of strong drink daily).

\section{Conflict of Interest}

There is no conflict of interest.

\section{Acknowledgements}

This work was supported by the Slovak Research and Development Agency (APVV) under the contract APVV15-0296, APVV-18-0312 and by the Slovak Grant Agency of the Ministry of Education, Science and Sport and the Slovak Academy of Science (VEGA), project VEGA 1/0392/17, VEGA 1/0266/20.

\section{References}

BEDROOD Z, RAMESHRAD M, HOSSEINZADEH H: Toxicological effects of Camellia sinensis (green tea): A review. Phytother Res 32: 1163-1180, 2018. https://doi.org/10.1002/ptr.6063

BHATTI SK, O'KEEFE JH, LAVIE CJ: Coffee and tea: perks for health and longevity? Curr Opin Clin Nutr Metab Care 16: 688-697, 2013. https://doi.org/10.1097/MCO.0b013e328365b9a0

CAO J, HAN J, XIAO H, QIAO J, HAN M: Effect of Tea Polyphenol compounds on anticancer drugs in terms of anti-tumor activity, toxicology, and pharmacokinetics. Nutrients 8: pii: E762, 2016. https://doi.org/10.3390/nu8120762

CARLSTRÖM M, LARSSON SC: Coffee consumption and reduced risk of developing type 2 diabetes: a systematic review with meta-analysis. Nutr Rev 76: 395-417, 2018. https://doi.org/10.1093/nutrit/nuy014

DE ROOS B, SAWYER JK, KATAN MB, RUDEL LL: Validity of animal models for the cholesterol-raising effects of coffee diterpenes in human subjects. Proc Nutr Soc 58: 551-557, 1999. https://doi.org/10.1017/S0029665199000725

DOEPKER C, FRANKE K, MYERS E, GOLDBERGER JJ, LIEBERMAN HR, O'BRIEN C, PECK J, TENENBEIN M, WEAVER C, WIKOFF D: Key findings and implications of a recent systematic review of the potential adverse effects of caffeine consumption in healthy adults, pregnant women, adolescents, and children. Nutrients 10: 2018. pii: E1536. https://doi.org/10.3390/nu10101536 
DYBKOWSKA E, SADOWSKA A, RAKOWSKA R, DĘBOWSKA M, ŚWIDERSKI F, ŚWIĄDER K: Assessing polyphenols content and antioxidant activity in coffee beans according to origin and the degree of roasting. Rocz Panstw Zakl Hig 68: 347-353, 2017.

FLANAGAN J, BILY A, ROLLAND Y, ROLLER M: Lipolytic activity of Svetol®, a decaffeinated green coffee bean extract. Phytother Res 28: 946-948, 2014. https://doi.org/10.1002/ptr.5085

HASANI-RANJBAR S, NAYEBI N, LARIJANI B, ABDOLLAHI M: A systematic review of the efficacy and safety of herbal medicines used in the treatment of obesity. World J Gastroenterol 15: 3073-3085, 2009. https://doi.org/10.3748/wjg.15.3073

HU J, WEBSTER D, CAO J, SHAO A: The safety of green tea and green tea extract consumption in adults - Results of a systematic review. Regul Toxicol Pharmacol 95: 412-433, 2018. https://doi.org/10.1016/j.yrtph.2018.03.019

HUANG J, WANG Y, XIE Z, ZHOU Y, ZHANG Y, WAN X: The anti-obesity effects of green tea in human intervention and basic molecular studies. Eur J Clin Nutr 68: 1075-1087, 2014. https://doi.org/10.1038/ejen.2014.143

ISLAM MT, TABREZ S, JABIR NR, ALI M, KAMAL MA, DA SILVA ARAUJO L, DE OLIVEIRA SANTOS JV, DA MATA AMOF, DE AGUIAR RPS, DE CARVALHO MELO CAVALCANTE AA: An insight into the therapeutic potential of major coffee components. Curr Drug Metab 19: 544-556, 2018. https://doi.org/10.2174/1389200219666180302154551

JANSSENS PL, HURSEL R, WESTERTERP-PLANTENGA MS: Nutraceuticals for body-weight management: The role of green tea catechins. Physiol Behav 162: 83-87, 2016. https://doi.org/10.1016/j.physbeh.2016.01.044

KARAK T, KUTU FR, NATH JR, SONAR I, PAUL RK, BORUAH RK, SANYAL S, SABHAPONDIT S, DUTTA AK: Micronutrients (B, Co, Cu, Fe, Mn, Mo, and $\mathrm{Zn}$ ) content in made tea (Camellia sinensis L.) and tea infusion with health prospect: A critical review. Crit Rev Food Sci Nutr 57: 2996-3034, 2017. https://doi.org/10.1080/10408398.2015.1083534

LI Y, WANG C, HUAI Q, GUO F, LIU L, FENG R, SUN C: Effects of tea or tea extract on metabolic profiles in patients with type 2 diabetes mellitus: a meta-analysis of ten randomized controlled trials. Diabetes Metab Res Rev 32: 2-10, 2016. https://doi.org/10.1002/dmrr.2641

LUDWIG IA, CLIFFORD MN, LEAN ME, ASHIHARA H, CROZIER A: Coffee: biochemistry and potential impact on health. Food Funct 5: 1695-1717, 2014. https://doi.org/10.1039/C4FO00042K

MAZZANTI G, Di SOTTO A, VITALONE A: Hepatotoxicity of green tea: an update. Arch Toxicol 89: 1175-1191, 2015. https://doi.org/10.1007/s00204-015-1521-x

MIELGO-AYUSO J, BARRENECHEA L, ALCORTA P, LARRARTE E, MARGARETO J, LABAYEN I: Effects of dietary supplementation with epigallocatechin-3-gallate on weight loss, energy homeostasis, cardiometabolic risk factors and liver function in obese women: randomised, double-blind, placebo-controlled clinical trial. Br J Nutr 111: 1263-1271, 2014. https://doi.org/10.1017/S0007114513003784

MOHAMED GA, IBRAHIM SRM, ELKHAYAT ES, EL DINE RS: Natural anti-obesity agents. Bull Fac Pharmacy Cairo University 52: 269-284, 2014. https://doi.org/10.1016/j.bfopcu.2014.05.001

ODŽAKOVIĆ B, DŽINIĆ N, KUKRIĆ Z, GRUJIĆ S: Effect of roasting degree on the antioxidant activity of different Arabica coffee quality classes. Acta Sci Pol Technol Aliment 15: 409-417, 2016. https://doi.org/10.17306/J.AFS.2016.4.39

ONAKPOYA I, TERRY R, ERNST E: The use of green coffee extract as a weight loss supplement: a systematic review and meta-analysis of randomised clinical trials. Gastroenterol Res Pract: 2011. pii: 382852. https://doi.org/10.1155/2011/382852

OZ HS: Chronic inflammatory diseases and green tea polyphenols. Nutrients 9, 2017. pii: E561. https://doi.org/10.3390/nu9060561

PAN H, GAO Y, TU Y: Mechanisms of body weight reduction by black tea polyphenols. Molecules 21, 2016. pii: E1659. https://doi.org/10.3390/molecules21121659

PAN MH, TUNG YC, YANG G, LI S, HO CT: Molecular mechanisms of the anti-obesity effect of bioactive compounds in tea and coffee. Food Funct 7: 4481-4491, 2016. https://doi.org/10.1039/C6FO01168C 
PAN J, JIANG Y, LV Y, LI M, ZHANG S, LIU J, ZHU Y, ZHANG H: Comparison of the main compounds in fuding white tea infusions from various tea types. Food Sci Biotechnol 27: 1311-1318, 2018. https://doi.org/10.1007/s10068-018-0384-3

RICCI E, VIGANÒ P, CIPRIANI S, SOMIGLIANA E, CHIAFFARINO F, BULFONI A, PARAZZINI F: Coffee and caffeine intake and male infertility: a systematic review. Nutr J 16: 37, 2017. https://doi.org/10.1186/s12937017-0257-2

RÍOS-HOYO A, GUTIÉRREZ-SALMEÁN G: New dietary supplements for obesity: what we currently know. Curr Obes Rep 5: 262-270, 2016. https://doi.org/10.1007/s13679-016-0214-y

ROTHENBERG DO, ZHOU C, ZHANG L: A review on the weight-loss effects of oxidized tea polyphenols. Molecules 23, 2018. pii: E1176. https://doi.org/10.3390/molecules23051176

SARRIÁ B, MARTÍNEZ-LÓPEZ S, SIERRA-CINOS JL, GARCÍA-DIZ L, MATEOS R, BRAVO-CLEMENTE L: Regularly consuming a green/roasted coffee blend reduces the risk of metabolic syndrome. Eur J Nutr 57 : 269-278, 2018. https://doi.org/10.1007/s00394-016-1316-8

SILVESTER AJ, ASEER KR, YUN JW: Dietary polyphenols and their roles in fat browning. J Nutr Biochem 64: 1 12, 2019. https://doi.org/10.1016/j.jnutbio.2018.09.028

SINGH AK, BISHAYEE A, PANDEY AK: Targeting histone deacetylases with natural and synthetic agents: an emerging anticancer strategy. Nutrients 10, 2018. pii: E731. https://doi.org/10.3390/nu10060731

SKRYPNIK K, SULIBURSKA J, SKRYPNIK D, PILARSKI Ł, REGUŁA J, BOGDAŃSKI P: The genetic basis of obesity complications. Acta Sci Pol Technol Aliment 16: 83-91, 2017. https://doi.org/10.17306/J.AFS.2017.2017.0442

SUNG J, HO CT, WANG Y: Preventive mechanism of bioactive dietary foods on obesity-related inflammation and diseases. Food Funct 9: 6081-6095, 2018. https://doi.org/10.1039/C8FO01561A

TABRIZI R, SANEEI P, LANKARANI KB, AKBARI M, KOLAHDOOZ F, ESMAILLZADEH A, NADI-RAVANDI S, MAZOOCHI M, ASEMI Z: The effects of caffeine intake on weight loss: a systematic review and doseresponse meta-analysis of randomized controlled trials. Crit Rev Food Sci Nutr 59: 2688-2696, 2019. https://doi.org/10.1080/10408398.2018.1507996

TAJIK N, TAJIK M, MACK I, ENCK P: The potential effects of chlorogenic acid, the main phenolic components in coffee, on health: a comprehensive review of the literature. Eur J Nutr 56: 2215-2244, 2017. https://doi.org/10.1007/s00394-017-1379-1

TAMURA H: Molecular basis of preventive effects of habitual coffee intake against chronic diseases. Yakugaku Zasshi 140: 1351-1363, 2020. https://doi.org/10.1248/yakushi.20-00150

TANG GY, MENG X, GAN RY, ZHAO CN, LIU Q, FENG YB, LI S, WEI XL, ATANASOV AG, CORKE H, LI HB: Health functions and related molecular mechanisms of tea components: an update review. Int J Mol Sci 20: 6196, 2019. https://doi.org/10.3390/ijms20246196

TUNNICLIFFE JM, SHEARER J: Coffee, glucose homeostasis, and insulin resistance: physiological mechanisms and mediators. Appl Physiol Nutr Metab 33: 1290-1300, 2008. https://doi.org/10.1139/H08-123

TÜRKÖZÜ D, TEK NA: A minireview of effects of green tea on energy expenditure. Crit Rev Food Sci Nutr 57: 254-258, 2017. https://doi.org/10.1080/10408398.2014.986672

UNACHUKWU UJ, AHMED S, KAVALIER A, LYLES JT, KENNELLY EJ: White and green teas (Camellia sinensis var. sinensis): variation in phenolic, methylxanthine, and antioxidant profiles. J Food Sci 75: C541-8, 2010. https://doi.org/10.1111/j.1750-3841.2010.01705.x

UNNO K, FURUSHIMA D, HAMAMOTO S, IGUCHI K, YAMADA H, MORITA A, HORIE H, NAKAMURA Y: Stress-reducing function of matcha green tea in animal experiments and clinical trials. Nutrients 10, 2018. pii: E1468. https://doi.org/10.3390/nu10101468

VÁZQUEZ CISNEROS LC, LÓPEZ-URIARTE P, LÓPEZ-ESPINOZA A, NAVARRO MEZA M, ESPINOZAGALLARDO AC, GUZMÁN ABURTO MB: Effects of green tea and its epigallocatechin (EGCG) content on body weight and fat mass in humans: a systematic review. Nutr Hosp 34: 731-737, 2017. https://doi.org/10.20960/nh.753

WILLEMS MET, ŞAHIN MA, COOK MD: Matcha green tea drinks enhance fat oxidation during brisk walking in females. Int J Sport Nutr Exerc Metab 28: 536-541, 2018. https://doi.org/10.1123/ijsnem.2017-0237 
WILLIAMSON G, DIONISI F, RENOUF M: Flavanols from green tea and phenolic acids from coffee: critical quantitative evaluation of the pharmacokinetic data in humans after consumption of single doses of beverages. Mol Nutr Food Res 55: 864-873, 2011. https://doi.org/10.1002/mnfr.201000631

YANG CS, ZHANG J, ZHANG L, HUANG J, WANG Y: Mechanisms of body weight reduction and metabolic syndrome alleviation by tea. Mol Nutr Food Res 60: 160-174, 2016. https://doi.org/10.1002/mnfr.201500428

YANG CS, WANG H, SHERIDAN ZP: Studies on prevention of obesity, metabolic syndrome, diabetes, cardiovascular diseases and cancer by tea. J Food Drug Anal 26: 1-13, 2018. https://doi.org/10.1016/j.jfda.2017.10.010

YASHIN A, YASHIN Y, WANG JY, NEMZER B: Antioxidant and antiradical activity of coffee. Antioxidants (Basel) 2: 230-245, 2013. https://doi.org/10.3390/antiox2040230

XIE C, CUI L, ZHU J, WANG K, SUN N, SUN C: Coffee consumption and risk of hypertension: a systematic review and dose-response meta-analysis of cohort studies. J Hum Hypertens 32: 83-93, 2018. https://doi.org/10.1038/s41371-017-0007-0

XU H, WANG Y, YUAN Y, ZHANG X, ZUO X, CUI L, LIU Y, CHEN W, SU N, WANG H, YAN F, LI X, WANG T, XIAO S: Gender differences in the protective effects of green tea against amnestic mild cognitive impairment in the elderly Han population. Neuropsychiatr Dis Treat 14: 1795-1801, 2018. https://doi.org/10.2147/NDT.S165618 